\title{
DETERMINAN DIVIDEND PA YOUT RATIO PERUSAHAAN MANUFAKTUR INDONESIA YANG GO PUBLIC
}

\author{
Muhammad Ikhsan ${ }^{1}$, Musripahtun Hilalia ${ }^{2}$, Farah Margaretha Leon ${ }^{3}$ \\ ${ }^{1}$ PT. Bank Rakyat Indonesia (Persero) Tbk \\ ${ }^{2}$ Lembaga Pengembangan Jasa Konstruksi Indonesia \\ ${ }^{3}$ Fakultas Ekonomi Bisnis Universitas Trisakti \\ icchanks12@gmail.com
}

\begin{abstract}
Abstrak
Penelitian ini bertujuan untuk menguji determinan dividend payout ratio (DPR) pada perusahaan manufaktur yang Go Public dan tercatat di Bursa Efek Indonesia dengan menggunakan data sekunder dari laporan keuangan tahun 2015 sampai 2019. Dividend payout ratio dapat dipengaruhi oleh free cash flow, likuiditas, ukuran perusahaan, leverage, profitabilitas, dan umur perusahaan. Metode penelitian menggunakan pendekatan metode kuantitatif. Sampel dipilih berdasarkan metode purposive sampling sehingga diperoleh sampel sebanyak 185 perusahaan-tahun pengamatan. Teknik analisis data yang digunakan adalah regresi berganda dengan data panel. Hasil penelitian menunjukkan bahwa profitabilitas berpengaruh negatif signifikan terhadap dividend payout ratio sedangkan free cash flow, likuiditas, ukuran perusahaan, leverage, dan umur perusahaan tidak berpengaruh terhadap DPR. Implikasi penelitian ini bagi Manajer sebaiknya lebih memperhatikan return on asset (ROA) perusahaan yang berpengaruh negatif terhadap DPR, sehingga untuk meningkatkan ROA perusahaan maka DPR sebaiknya diturunkan, akan tetapi untuk menjaga harga saham dan persepsi perusahaan di mata investor maka manajer harus menjelaskan dalam RUPS bahwa laba digunakan untuk memperkuat struktur modal dan diinvestasikan kembali pada sektor-sektor produktif sehingga dalam jangka panjang akan meningkatkan nilai perusahaan. Penelitian selanjutnya sebaiknya tidak hanya menggunakan variabel yang sudah digunakan dalam penelitian ini tetapi bisa memperbanyak indikator lainnya yang dapat mempengaruhi DPR antara lain pertumbuhan penjualan dan risiko bisnis.
\end{abstract}

Kata kunci : rasio pembayaran dividen; arus kas bebas; profitabilitas; likuiditas; leverage; ukuran perusahaan; umur perusahaan

\begin{abstract}
This study aims to examine the determinants of the dividend payout ratio (DPR) in manufacturing companies that go public and listed on the Indonesia Stock Exchange using secondary data from financial reports for 2015 to 2019. Dividend payout ratio can be influenced by free cash flow, liquidity, firm size, leverage, profitability, and the age of the firm. The research method uses a quantitative method approach. The sample was selected based on the purposive sampling method in order to obtain a sample of 185 firm-years of observation. The data analysis technique used is panel data regression. The results showed that profitability had a negative effect on the dividend payout ratio, while free cash flow, liquidity, firm size, leverage, and firm age had no effect on the dividend payout ratio. The research implication that managers should pay attention to the return on assets (ROA) of the company which has a negative effect on the DPR, so that to increase the company's $R O A$, the DPR should be lowered, but to maintain share prices and company perceptions in the eyes of investors, managers must explain in the RUPS that the company's profit is to build a capital structure and reinvested in productive sectors so that in the long run it will increase company's value. Further research should not only use the variables that have been used in this study but can multiply other indicators that can affect the dividend payout ratio, including sales growth and business risk.
\end{abstract}

Keywords : firm age; firm size ; dividend payout ratio; leverage; liquidity; profitability 


\section{Pendahuluan}

Industri manufaktur menjadi salah satu bisnis di Indonesia yang terus memperlihatkan perkembangannya dari waktu ke waktu dan memberikan kontribusi terbesar terhadap PDB di Indonesia. Perusahaan manufaktur adalah salah satu industri yang aktivitas bisnisnya memanfaatkan dan memerlukan banyak hal mulai dari penggunaan mesin, peralatan dan teknologi yang canggih, serta tenaga kerja tertentu. Seiring dengan perkembangan perusahaan manufaktur di Indonesia, suatu perusahaan juga harus mampu menciptakan nilai (value creation) bagi pemegang saham (share holders). Nilai-nilai tersebut diwujudkan ke dalam meningkatnya harga saham dan dividen perusahaan. Ketika manajemen memutuskan untuk membayar dividen, manajemen perlu mempertimbangkan kebijakan pembiayaan alternatif untuk membiayai kegiatan dan ekspansi perusahaan. Dalam pengertian ini, konflik kepentingan mungkin terjadi antara pengelola dan pemilik. Dengan demikian, pembayaran dividen dapat digunakan untuk mengurangi konflik tersebut. Manajer dapat membayar dividen dalam bentuk uang tunai atau saham (stuck dividends). Stuck dividends bukanlah dividen yang sebenarnya karena tidak ada uang yang dibayarkan oleh perusahaan (Al- Fasfus, 2020).

Pemangku kepentingan dan pemegang saham suatu perusahaan tampaknya memiliki pandangan berbeda mengenai apakah perusahaan mereka harus membayar dividen atau menahan pendapatan, dan bagaimana menentukan waktu dan volume pembayaran dividen (Le et al, 2019). Kebijakan dividen suatu perusahaan akan melibatkan dua pihak yang berkepentingan dan saling bertentangan, yaitu kepentingan pemegang saham yang mengharapkan dividen, dengan kepentingan perusahaan terhadap laba ditahan. Besar kecilnya dividen yang akan dibayarkan oleh perusahaan tergantung pada kebijakan dividen dari masing-masing perusahaan. Pembayaran dividen merupakan arus kas keluar. Semakin kuat posisi kas perusahaan, berarti semakin besar kemampuan perusahaan untuk membayar dividen kepada pemegang saham. Kas tersebut biasanya menimbulkan konflik kepentingan antara manajer dan pemegang saham. Manajer lebih menginginkan kas tersebut diinvestasikan kembali pada aset-aset perusahaan untuk meningkatkan insentif yang diterima dan meningkatkan omzet penjualan, sedangkan pemegang saham lebih menginginkan kas tersebut dibagikan sebagai dividen.

Manajemen memandang dividen kas sebagai arus kas keluar yang dapat mengurangi kas perusahaan, oleh karenanya kesempatan untuk melakukan investasi dengan kas yang dibagikan sebagai dividen tersebut menjadi berkurang bagi para pihak manajemen. Dividen kas dapat menjadi signal mengenai kecukupan kas perusahaan untuk membayar bunga atau bahkan melunasi pokok pinjaman bagi para kreditur. Kurangnya kecukupan likuiditas dapat menyebabkan manajemen menahan kas untuk diinvestasikan kembali ke bisnis lain serta menyediakan beberapa sumber keuangan terutama selama krisis keuangan. Sebagai akibat dari kurangnya likuiditas, perusahaan dapat menggunakan keuntungan untuk membiayai aktivitasnya yang akan menurunkan rasio pembayaran dividen (Al- Fasfus, 2020). Pembayaran dividen khususnya cash dividend kepada para pemegang saham sangat tergantung pada posisi kas yang tersedia. Perusahaan dapat membayar arus kas bebas sebagai dividen, menggunakan kas untuk mengurangi hutang atau pembiayaan ekuitas, menyimpan kas sebagai tabungan pencegahan, atau membelanjakan arus kas tambahan untuk investasi (Yeo, 2018). Berbagai kondisi perusahaan dapat mempengaruhi nilai aliran kas bebas, misalnya bila perusahaan memiliki aliran kas bebas tinggi dengan tingkat pertumbuhan rendah maka aliran kas bebas ini seharusnya didistribusikan kepada pemegang saham, tetapi bila perusahaan memiliki aliran kas bebas tinggi dan tingkat pertumbuhan 
tinggi maka aliran kas bebas ini dapat ditahan sementara dan bisa dimanfaatkan untuk investasi pada periode mendatang.

Sari dan Masdupi (2019) menjelaskan untuk mengukur kebijakan dividen perusahaan itu sendiri digunakan dividend payout ratio (DPR). DPR mencerminkan persentase dividen dari laba per lembar sahamnya yang diperoleh oleh perusahaan yang dibagikan sebagai dividen kepada pemegang saham. Perusahaan harus mempertimbangkan berbagai aspek agar dapat memberikan dividen yang optimal bagi perusahaan dan pemegang saham, termasuk faktor-faktor yang mempengaruhi perusahaan dalam menentukan dividen. Faktor-faktor yang mempengaruhi dividend payout ratio antara lain free cash flow, likuiditas, ukuran perusahaan, leverage, profitabilitas, dan umur perusahaan.

Berdasarkan latar belakang diatas dan penelitian terdahulu, dilakukan penelitian di Indonesia khususnya untuk perusahaanperusahaan manufaktur. Penelitian sebelumnya menunjukkan bahwa free cash flow, likuditas, leverage dan profitabilitas merupakan faktorfaktor yang berpengaruh terhadap dividend payout ratio namun ukuran bank dan umur bank ditemukan memiliki hubungan yang tidak signifikan dengan dividend payout ratio. Oleh karena itu penelitian ini berjudul Determinan Dividend payout ratio Perusahaan Manufaktur Indonesia yang Go Public. Penelitian ini bertujuan untuk menganalisis ada pengaruh antara free cash flow, likuditas, ukuran perusahaan, profitabilitas, leverage, umur perusahaan dengan dividend payout ratio.

\section{Landasan Teori}

Dividen merupakan laba bersih perusahaan yang sebagian dibagikan kepada pemegang saham berdasarkan dengan proporsi kepemilikan saham yang dimiliki. Besaran nilai dan waktu pembayaran dividen berdasarkan pada Rapat Umum Pemegang Saham (RUPS). Terdapat beberapa jenis dividen yaitu (1) dividen Kas (cash dividend), (2) dividen aktiva selain kas (property dividend), (3) dividen hutang (scrip dividend), (4) dividen likuidasi dan (5) dividen saham (Samrotun, 2015). Kebijakan dividen merupakan kebijakan yang dibuat oleh perusahaan untuk menentukan apakah laba yang dihasilkan oleh perusahaan akan dibagikan kepada pemegang saham berupa dividen atau sebagai laba ditahan. Kebijakan dividen tergambar pada dividend payout ratio, yaitu presentase laba yang dibagikan dalam bentuk dividen tunai, artinya besar kecilnya dividend payout ratio akan mempengaruhi keputusan investasi pemegang saham dan di sisi lain berpengaruh pada kondisi keuangan perusahaaan (Yani dan Dana, 2017). Rasio Pembayaran Dividen ini sangat penting bagi Investor, hal ini dikarenakan sebagian besar Investor menginginkan arus dividen yang berkelanjutan dari perusahaan sehingga tren yang konsisten dalam rasio ini biasanya lebih penting daripada tinggi rendah rasionya. Sebaliknya, perusahaan yang rasionya memiliki tren penurunan akan mengkhawatirkan investor karena merupakan indikasi penurunan kinerja operasi pada perusahaan tersebut. Tahir dan Mushtaq (2016) merumuskan dividend payout ratio sebagai berikut:

\section{$D P R=$ Dividend per share $/$ Eearning per share}

Keputusan suatu perusahaan untuk membagikan dividen serta besarnya dividen yang dapat dibagikan kepada para pemegang saham sangat tergantung pada posisi kas perusahaan tersebut. Pembagian tersebut bisa dilakukan setelah perusahaan melakukan pembelanjaan modal (capital expenditure) seperti pembelian aset tetap secara tunai. Meskipun perusahaan dapat memperoleh laba yang tinggi namun apabila posisi kas menunjukkan keadaan yang tidak begitu baik, perusahaan mungkin tidak dapat membayar dividen. Oleh karena dividen merupakan arus kas keluar maka semakin kuat posisi kas perusahaan, akan mempengaruhi besarnya kemampuan perusahaan dalam membayar 
dividen. Zurriah dan Sembiring (2018) mengemukakan bahwa free cash flow atau aliran kas bebas merupakan salah satu indikator untuk mengukur kemampuan perusahaan untuk mengendalikan keuntungan bagi para pemegang saham melalui pengurangan utang, peningkatan dividen atau pembelian saham kembali dan dengan hal tersebut nilai perusahaan juga akan ikut meningkat. Saputro et al (2017) merumuskan free cash flow sebagai berikut :

\section{Free Cash Flow = (aliran kas operasi - aliran kas untuk pembelian aset tetap) / total aset}

Gaol (2015) mengemukakan analisis likuiditas digunakan untuk mengukur kemampuan perusahaan dalam memenuhi kewajiban finansial jangka pendeknya, baik kewajiban dalam membiayai proses produksi maupun kewajiban keluar perusahaan. Rasio likuiditas digunakan untuk mengukur kemampuan perusahaan dalam memenuhi kewajiban jangka pendek (Mayasari et al, 2018). Rasio ini digunakan untuk mengukur seberapa likuidnya suatu perusahaan. Jika perusahaan mampu memenuhi kewajibannya berarti perusahaan tersebut likuid, sedangkan jika perusahaan tidak mampu memenuhi kewajibannya berarti perusahaan tersebut tidak likuid. Cara mengukur perusahaan likuid atau tidak yaitu dengan membandingkan komponen yang ada pada neraca, yaitu aset lancar dengan hutang lancar atau biasa disebut dengan current ratio. Pengukuran ini dapat dilakukan untuk beberapa periode sehingga terlihat perkembangan likuiditas perusahaan dari waktu ke waktu. Current ratio menunjukkan seberapa baik perusahaan mampu membayar kreditor dari aset lancarnya dan salah satu ukuran untuk mengetahui apakah ada cukup aset lancar untuk memenuhi kewajiban lancar dengan margin keamanan. Aset lancar diasumsikan dapat dikonversi menjadi kas dalam waktu 1 tahun, dan kewajiban lancar adalah hutang jangka pendek yang jatuh tempo dalam 1 tahun atau kurang. Tahir dan Mushtaq (2016) merumuskan current ratio sebagai berikut :

\section{Current ratio $=$ Current Asset $/$ Current liabilities}

Pada umumnya perusahaan besar biasanya memiliki aktivitas yang lebih banyak, mempunyai dampak yang lebih besar terhadap masyarakat dan mendapatkan perhatian serta dukungan lebih dari kalangan publik daripada perusahaan kecil. Ukuran perusahaan (size) adalah menggambarkan besar kecilnya suatu perusahaan yang ditunjukkan oleh total aktiva, jumlah penjualan, rata -rata total penjualan, dan rata -rata total aktiva. Ukuran perusahaan merupakan rasio nilai logaritma natural dari total asset (Utomo et al, 2016). Ukuran perusahan (size) diproksikan pada jumlah asset yang di miliki oleh perusahaan, dimana semakin besar asset yang dimiliki perusahaan yang diikuti dengan pemanfaat asset yang optimal akan berpengaruh terhadap nilai perusahaan yang di tunjukan pada harga saham yang tinggi dibandingkan dengan nilai bukunya dan sebaliknya bila asset yang besar tidak dimanfaatkan secara optimal maka nilai perusahaan akan turun atau harga saham akan rendah dibandingkan dengan nilai bukunya. AlFasfus (2020) mendefinisikan ukuran perusahaan sebagai berikut :

\section{Ukuran perusahaan $=$ Log Total Aset perusahaan}

Munawar (2019) menyebutkan bahwa pengukuran utang perusahaan dapat dinilai berdasar rasio leverage untuk mengetahui seberapa baik perusahaan dalam mengelola porsi debt-nya. Rasio hutang terhadap ekuitas (debt to equty ratio) membandingkan hutang dengan ekuitas pemilik daripada membandingkan hutang dengan aset. Ekuitas pemegang saham atau pemilik adalah klaim yang dimiliki pemegang saham atas aset perusahaan setelah semua kreditur dan debitur dibayar. Ini adalah kekayaan bersih perusahaan, dan dihitung dengan 
mengurangkan total kewajiban dari total aset. Rasio hutang terhadap ekuitas adalah alat yang menyoroti sejauh mana hutang ditutupi oleh dana pemegang saham. Rumus rasio hutang terhadap ekuitas adalah total kewajiban dibagi total ekuitas pemegang Saham. Kadangkadang, hanya hutang jangka panjang yang mengandung bunga yang dipertimbangkan daripada total kewajiban dalam penghitungan (Singal, 2020). Struktur permodalan yang lebih tinggi dimiliki oleh utang menyebabkan pihak manjemen akan memprioritaskan pelunasan kewajiban terlebih dahulu sebelum membagikan dividen. Perusahaan yang memiliki rasio utang lebih besar seharusnya membagikan dividen lebih kecil karena laba yang diperoleh digunakan untuk melunasi kewajiban. Tahir dan Mushtaq (2016) merumuskan debt equity ratio sebagai berikut :

\section{DER = Total debts / Total equity}

Singal (2020) menyebutkan bahwa tanpa profitabilitas, bisnis tidak akan bertahan dalam jangka panjang. Rasio profitabilitas menentukan apakah suatu perusahaan memiliki kemampuan untuk memperoleh keuntungan di masa depan. Perusahaan dapat menunjukkan keuntungan dengan menggunakan rasio profitabilitas misalnya dengan Return on asset (ROA). ROA mengukur seberapa baik perusahaan menggunakan asetnya untuk menghasilkan laba bersih. Jadi rasio ini menunjukkan bisnis mana yang dapat menghasilkan keuntungan besar dengan aset kecil dan dihitung sebagai net income dibagi dengan total aset. Rumus ini mengukur berapa banyak keuntungan, setelah pajak, diperoleh dari total modal yang disumbangkan oleh kreditor dan pemilik. Semakin kecil ROA perusahaan, semakin kecil tingkat keuntungan yang dicapai oleh perusahaan dalam hal penggunaan aset. Tahir dan Mushtaq (2016) merumuskan return on asset sebagai berikut :

\section{ROA $=$ Net income/ Total assets}

Umur perusahaan menunjukkan kemampuan perusahaan dalam mengatasi kesulitan dan hambatan yang dapat mengancam kehidupan perusahaan sehingga semakin lama perusahaan berdiri, maka semakin mampu perusahaan tersebut meningkatkan kepercayaan investor (Santioso dan Chandra, 2012). Menurut Tamimi (2014), dalam ekonomi dan manajemen, usia perusahaan dan institusi dibagi menjadi beberapa langkah. Dalam literatur ilmu-ilmu tersebut, beberapa model telah disajikan untuk usia perusahaan yang dalam kerangka model tersebut, perusahaan dan institusi mengikuti kebijakan tertentu dengan mempertimbangkan setiap langkah usia ekonominya. Beberapa peneliti mengemukakan empat langkah untuk mendeskripsikan siklus umur perusahaan yaitu (1) tahap pengenalan, (2) tahap pertumbuhan, (3) tahap kematangan, dan (4) tahap penurunan. Umur perusahaan adalah lamanya waktu antara tahun berdirinya perusahaan dengan tahun berjalan. Perusahaan memiliki siklus umur dan kemungkinan pembagian keuntungan pada awal pendirian atau awal masuknya bursa efek antar pemegang saham berbeda dengan jumlah pembagian keuntungan pada saat jatuh tempo atau tahapan pertumbuhan atau tahapan resesi. Hubungan antara umur perusahaan dengan dividen perusahaan bersifat searah. Dengan kata lain, semakin bertambahnya usia perusahaan pada perusahaan maka jumlah deviden perusahaan yang dipertimbangkan akan meningkat pula. Santioso dan Chandra (2012) mendefinifikan umur perusahaan sebagai berikut :

\section{Umur perusahaan = Tahun ke-n (tahun first issue di BEI)}

Manajemen perusahaan harus berusaha memaksimumkan kesejahteraan pemegang saham melalui kewenangan yang diberikan dalam membuat keputusan baik berupa keputusan investasi, keputusan pendanaan, dan keputusan dividen. Kebijakan dividen tergambar pada dividend payout ratio, yaitu presentase laba yang dibagikan dalam bentuk dividen tunai. Salah satu alat pengukur kebijakan dividen perusahaan adalah free cash flow. Biasanya, free cash flow mewakili kas yang tersisa dari aktivitas operasional bisnis yang dapat digunakan untuk pembayaran 
dividen, ekspansi, atau pelunasan utang. AlFasfus (2020) menyimpulkan bahwa adanya hubungan signifikan yang positif antara free cash flow dengan kemampuan perusahaan untuk membayar dividen. Semakin besar free cash flow yang tersedia dalam suatu perusahaan, maka semakin sehat perusahaan tersebut karena memiliki kas yang tersedia untuk pertumbuhan, pembayaran hutang, dan dividen.

Likuiditas perusahaan menunjukkan kemampuan perusahaan mendanai operasional perusahaan dan melunasi kewajiban jangka pendeknya. Oleh karena itu perusahaan yang memiliki likuiditas baik maka kemungkinan pembayaran dividen lebih baik pula. Likuiditas perusahaan dapat diukur melalui rasio keuangan misalnya current ratio. Penelitian menyebutkan terdapat pengaruh signifikan antara current ratio terhadap dividend payout ratio (Saputra dan Pramurza, 2019). Berdasarkan teori siklus hidup, pembayaran dividen memiliki hubungan positif dengan ukuran perusahaan karena arus kas perusahaan besar dan matang berasal dari pendapatan perusahaan bukan kontribusi investor. Oleh karena itu ukuran perusahaan memberikan pengaruh positif yang signifikan untuk membayar dividen lebih banyak dan konsisten (Jaara et al, 2019). Faktor lain yang mempengaruhi keputusan pembayaran dividien yaitu rasio leverage.

Leverage, atau debt ratio, dihitung dengan membagi total kewajiban dengan total aset dan dikatakan bahwa leverage memiliki pengaruh yang signifikan terhadap hasil perusahaan secara keseluruhan. Penelitian yang dilakukan Al- Fasfus (2020) menemukan bahwa leverage merupakan faktor yang mempengaruhi rasio pembayaran dividen di bank-bank Yordania. Return on asset (ROA) menjadi salah satu variable yang banyak digunakan peneliti dalam mengukur profitabilitas suaru perusahaan. Le et al (2019) menunjukkan bahwa pembayaran dividen berhubungan positif dengan profitabilitas. Selain itu faktor usia perusahaan juga dapat mempengaruhi rasio pembayaran dividen yang dilakukan perusahaan. Penelitian yang dilakukan Tamimi (2014) menunjukkan hubungan yang positif dan signifikan antara umur perusahaan dan rasio dividen.

Berdasarkan uraian teoritis dan hasil-hasil penelitian maka kerangka konseptual dari penelitian ini adalah sebagai berikut :

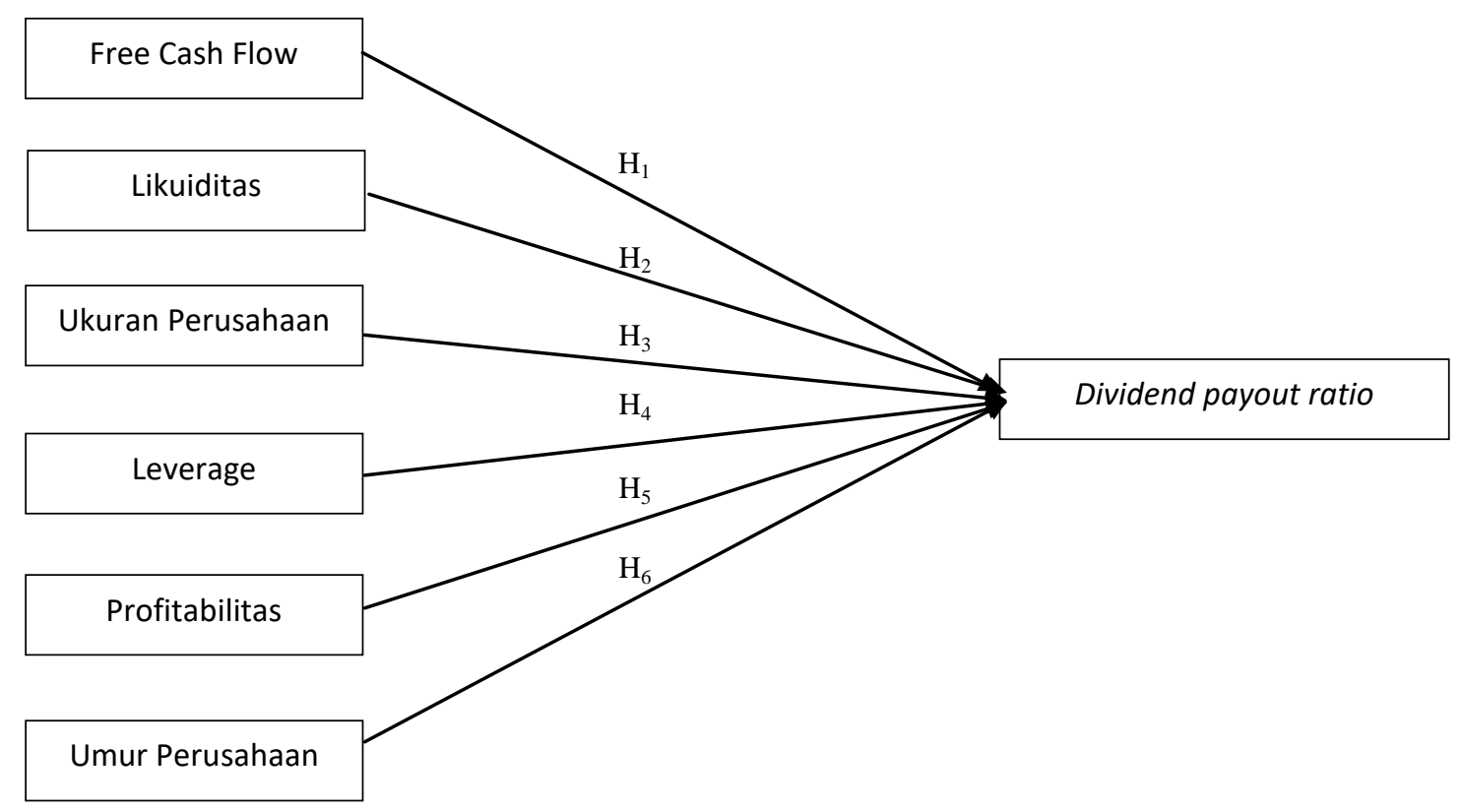

Gambar 1

Kerangka Konseptual Penelitian

\section{Pengembangan Hipotesa}

Penampakan free cash flow pada perusahaan menunjukkan kas yang bebas untuk digunakan sebagai pelunasan hutang atau imbal hasil ke pemegang saham. Penelitian menunjukkan free cash flow dari 
perusahaan memiliki pengaruh signifikan terhadap keputusan pembayaran dividen. AlFasfus (2020) menyimpulkan bahwa adanya hubungan signifikan yang positif antara free cash flow dengan kemampuan perusahaan untuk membayar dividen. Penelitian mengenai free cash flow dengan kebijakan dividen di Indonesia dilakukan Suherman et al (2015) menyimpulan free cash flow berpengaruh positif secara signifikan terhadap kebijakan deviden. Penelitian lainnya menyatakan hubungan terbalik antara free cash flow dan pembayaran dividen seperti Hasana et al (2018) menunjukkan bawah free cash flow berpengaruh negatif terhadap dividend payout ratio.

Berdasarkan pembahasan di atas, maka dirumuskan hipotesis sebagai berikut:

\section{$\mathrm{H}_{1}$ : Ada pengaruh antara free cash flow dengan dividend payout ratio}

Likuiditas perusahaan menunjukkan kemampuan perusahaan mendanai operasional perusahaan dan melunasi kewajiban jangka pendeknya, yang dapat diukur melalui rasio keuangan seperti current ratio, quick ratio dan cash acid-ratio. Penelitian sebelumnya sudah memberikan pemikiran awal mengenai pengaruh likuiditas perusahaan terhadap kebijakan jumlah pembagian dividen. Al-Fasfus (2020) menemukan bahwa likuiditas merupakan faktor yang mempengaruhi rasio pembayaran dividen. Yani dan Dana (2017) menunjukkan bahwa likuiditas perusahaan berpengaruh positif dan signifikan terhadap kebijakan dividen. Saputra dan Pramurza (2019) dalam penelitiannya menyebutkan terdapat pengaruh signifikan Current ratio (CR) terhadap Dividend payout ratio (DPR).

Berdasarkan pembahasan di atas, maka dirumuskan hipotesis sebagai berikut:

\section{$\mathrm{H}_{2}$ : Ada pengaruh antara likuiditas dengan dividend payout ratio rasio}

Penelitian yang dilakukan Tahir dan Mushtaq (2016) menunjukkan hubungan positif yang signifikan antara ukuran perusahaan dengan pembayaran dividen. Jaara et al (2019) serta Yani dan Dana (2017) juga menyebutkan jika ukuran perusahaan menunjukkan pengaruh positif yang signifikan untuk membayar dividen lebih banyak dan konsisten. Penelitian lainnya seperti Samrotun (2015) menyebutkan adanya hubungan negatif yang signifikan antara ukuran perusahaan dengan dividend payout ratio.

Berdasarkan penjelasan diatas, maka dirumuskan hipotesis sebagai berikut:

\section{$\mathrm{H}_{3}$ : Ada pengaruh antara ukuran perusahaan dengan dividend payout ratio}

Rasio leverage yang banyak digunakan sebagai faktor determinan dalam studi keuangan perusahaan adalah Debt Equity Ratio (DER). Penelitian yang dilakukan Al- Fasfus (2020) menemukan bahwa leverage merupakan faktor yang mempengaruhi rasio pembayaran dividen di bank-bank Yordania. Penelitian lain seperti yang dilakukan Samrotun (2015) juga menyebutkan DER berpengaruh positif signifikan terhadap kebijakan dividen. Penelitian lainnya seperti Tahir dan Mushtaq (2016) menyebutkan leverage keuangan berpengaruh negatif signifikan terhadap pembayaran dividen.

Berdasarkan penjelasan diatas, maka dirumuskan hipotesis sebagai berikut:

\section{$\mathrm{H}_{4}$ : Ada pengaruh antara leverage dengan dividend payout ratio}

Profitabilitas perusahaan menjadi perhatian baik bagi manajer maupun pemilik dan merupakan salah satu penentu utama pembayaran dividen perusahaan. Profitabilitas mewakili kinerja bisnis dan kemampuannya untuk menghasilkan laba yang akan memastikan pertumbuhan dan keberlanjutannya. Salah satu rasio yang digunakan untuk mengukur profitabilitas perusahaan yaitu Return on asset (ROA). Penelitian Al- Fasfus (2020) menemukan bahwa profitabilitas merupakan faktor yang mempengaruhi rasio pembayaran dividen di bank-bank Yordania. Le et al (2019) menunjukkan bahwa pembayaran dividen berhubungan positif dengan profitabilitas. Penelitian yang dilakukan Tahir dan Mushtaq (2016) juga menunjukkan hubungan positif yang signifikan antara profitabilitas dengan pembayaran dividen. Penelitian yang dilakukan di Indonesia seperti Samrotun (2015) menyimpulkan variabel ROA berpengaruh positif terhadap kebijakan dividen. Yani dan Dana (2017) juga menyimpulkan bahwa profitabilitas berpengaruh positif dan signifikan terhadap kebijakan dividen. Penelitian lain 
memberikan hasil yang berbeda diantaranya penelitian Silfiana dan Rachmawati (2016) serta Hasana et al (2018) yang menemukan profitabilitas bepengaruh negatif terhadap kebijakan dividen.

Berdasarkan penjelasan diatas, maka dirumuskan hipotesis sebagai berikut:

\section{$\mathrm{H}_{5}$ : Ada pengaruh antara profitabilitas perusahaan dengan dividend payout ratio}

Beberapa penelitian menggunakan faktor umur perusahaan sebagai salah satu faktor yang mempengaruhi kebijakan perusahaan dalam menetapkan dividen bagi pemegang saham. Penelitian yang dilakukan Tamimi (2014) dan Darmawan (2011) menunjukkan hubungan yang positif dan signifikan antara umur perusahaan dan rasio dividen. Penelitian lain menemukan hubungan yang negatif yang siginifikan antara umur perusahaan dengan kebijakan pembayaran dividen seperti Al-Sabah (2015).

Berdasarkan penjelasan diatas, maka dirumuskan hipotesis sebagai berikut:

$\mathrm{H}_{6}$ : Ada pengaruh antara umur perusahaan dengan dividend payout ratio

\section{Metode Penelitian \\ Metode Pengambilan Sampel}

Objek penelitian ini adalah perusahaanperusahaan manufaktur yang terdaftar di Bursa Efek Indonesia. Data dalam penelitian ini merupakan data sekunder dari laporan keuangan dan sumber data dalam penelitian ini diperoleh dari website Bursa Efek Indonesia (www.idx.co.id) dan website Bloomberg. Peneliti menentukan sektor industri manufaktur karena pada sektor ini memiliki jumlah perusahaan yang paling banyak dibandingkan dengan sektor perusahaan yang lain dengan harapan peneliti mendapatkan jumlah sampel yang besar karena perusahaan setiap tahunnya belum tentu menetapkan kebijakan dividennya.

\section{Sumber Data}

Penelitian ini mengambil populasi perusahaan-perusahaan manufaktur yang listing di Bursa Efek Indonesia dari tahun 2015-
2019 sebanyak 184 perusahaan yang terdiri dari 77 perusahaan di sektor industri dasar dan kimia, 51 perusahaan di sektor aneka industri dan 56 perusahaan di sektor industry barang konsumsi. Selanjutnya pengambilan sampel dilakukan dengan metode purposive sampling, dari metode tersebut didapatkan sampel penelitian sebanyak 37 perusahaan pada sektor manufaktur yang telah memenuhi kriteria tertentu. Kriteria-kriteria yang digunakan dalam penelitian ini adalah sebagai berikut :

Tabel 1

\section{Kriteria Penarikan Sampel}

\begin{tabular}{ccc}
\hline Kriteria & & Jumlah \\
\hline Perusahaan-perusahaan & sektor & 184
\end{tabular}

manufaktur yang telah go public dan terdaftar di Bursa Efek Indonesia (BEI)

untuk periode 2015-2019

Perusahaan yang tidak memberikan dividen selama 5 tahun berturut-turut

Perusahaan yang memberikan dividen

dalam mata uang US Dollar

Perusahaan tidak mempunyai data data free cash flow, likuiditas, ukuran perusahaan, leverage, profitabilitas, dan umur perusahaan

Jumlah data yang dapat dijadikan

sampel

\section{Identifikasi dan Pengukuran Tabel}

Identifikasi variabel pada penelitian ini yaitu untuk mengetahui hubungan antara, variabel independen (free cash flow, likuiditas, ukuran perusahaan, leverage, profitabilitas dan umur perusahaan) terhadap variabel dependen (dividend payout ratio), yang masing-masing variabel pengukurannya sebagai berikut :

\section{Tabel 2}

Variabel dan Pengukuran

\begin{tabular}{|c|c|c|c|c|}
\hline $\begin{array}{c}\text { Jenis } \\
\text { Variabel }\end{array}$ & $\begin{array}{c}\text { Nama } \\
\text { Variabel }\end{array}$ & $\begin{array}{c}\text { Simb } \\
\text { ol }\end{array}$ & $\begin{array}{c}\text { Definisi } \\
\text { Operasio } \\
\text { nal } \\
\text { Variabel }\end{array}$ & $\begin{array}{c}\text { Sumb } \\
\text { er }\end{array}$ \\
\hline $\begin{array}{c}\text { Variable } \\
\text { Depende } \\
n\end{array}$ & $\begin{array}{l}\text { Dividend } \\
\text { payout } \\
\text { ratio }\end{array}$ & DPR & $\begin{array}{l}\text { Dividend } \\
\text { per share/ } \\
\text { EPS }\end{array}$ & $\begin{array}{c}\text { Tahir } \\
\text { dan } \\
\text { Musht } \\
\text { aq } \\
(2016)\end{array}$ \\
\hline $\begin{array}{l}\text { Variable } \\
\text { Indepen }\end{array}$ & $\begin{array}{l}\text { Free cash } \\
\text { flow }\end{array}$ & FCF & $\begin{array}{l}\text { (aliran kas } \\
\text { operasi - }\end{array}$ & $\begin{array}{l}\text { Saputr } \\
\text { o et al }\end{array}$ \\
\hline
\end{tabular}




\begin{tabular}{|c|c|c|c|c|}
\hline $\begin{array}{c}\text { Jenis } \\
\text { Variabel }\end{array}$ & $\begin{array}{c}\text { Nama } \\
\text { Variabel }\end{array}$ & $\begin{array}{c}\text { Simb } \\
\text { ol }\end{array}$ & $\begin{array}{c}\text { Definisi } \\
\text { Operasio } \\
\text { nal } \\
\text { Variabel }\end{array}$ & $\begin{array}{c}\text { Sumb } \\
\text { er }\end{array}$ \\
\hline \multirow[t]{6}{*}{ den } & & & $\begin{array}{l}\text { aliran kas } \\
\text { untuk } \\
\text { pembelian } \\
\text { aset } \\
\text { tetap) / } \\
\text { total aset }\end{array}$ & (2017) \\
\hline & Liquiditas & $\begin{array}{c}\text { Curre } \\
\text { nt } \\
\text { ratio }\end{array}$ & $\begin{array}{l}\text { Current } \\
\text { Asset / } \\
\text { Current } \\
\text { liabilities }\end{array}$ & $\begin{array}{c}\text { Tahir } \\
\text { dan } \\
\text { Musht } \\
\text { aq } \\
\text { (2016) }\end{array}$ \\
\hline & $\begin{array}{l}\text { Ukuran } \\
\text { Perusaha } \\
\text { an }\end{array}$ & SIZE & $\begin{array}{l}\text { Log Total } \\
\text { Asset } \\
\text { perusahaa } \\
\mathrm{n}\end{array}$ & $\begin{array}{c}\text { Al- } \\
\text { Fasfus } \\
(2020)\end{array}$ \\
\hline & Leverage & DER & $\begin{array}{l}\text { Total } \\
\text { debts/ } \\
\text { Total } \\
\text { equity }\end{array}$ & $\begin{array}{c}\text { Tahir } \\
\text { dan } \\
\text { Musht } \\
\text { aq } \\
\text { (2016) }\end{array}$ \\
\hline & $\begin{array}{l}\text { Profitabili } \\
\text { tas }\end{array}$ & ROA & $\begin{array}{l}\text { Net } \\
\text { income/ } \\
\text { Total } \\
\text { assets }\end{array}$ & $\begin{array}{c}\text { Tahir } \\
\text { dan } \\
\text { Musht } \\
\text { aq } \\
\text { (2016) }\end{array}$ \\
\hline & $\begin{array}{l}\text { Umur } \\
\text { Perusaha } \\
\text { an }\end{array}$ & AGE & $\begin{array}{l}\text { Tahun ke- } \\
\mathrm{n} \text { (tahun } \\
\text { first issue } \\
\text { di BEI) }\end{array}$ & $\begin{array}{c}\text { Santio } \\
\text { so dan } \\
\text { Chand } \\
\text { ra } \\
(2012)\end{array}$ \\
\hline
\end{tabular}

\section{Metode Analisis Data dan Model Penelitian \\ Metode Analisis Data}

Alat analisis yang digunakan untuk menguji hipotesis yang dirumuskan adalah regresi berganda dengan pendekatan data panel. Uji hipotesis dilakukan dengan menggunakan uji statistik $F$ untuk menguji secara bersama-sama (simultan) antara free cash flow, likuiditas, leverage, firm size, prifitabilitas dan ukuran perusahaan berpengaruh secara signifikan terhadap kebijakan deviden perusahaan, di mana hasil signifikansi dari $\mathrm{F}$ hitung harus di bawah tingkat signifikansi alpha yang telah ditetapkan yakni sebesar 5\%. Distribusi $t$ dilakukan untuk menguji secara parsial antara free cash flow, likuditas, leverage, ukuran perusahaan, profitabilitas, dan umur perusahaan berpengaruh secara signifikan terhadap kebijakan dividend payout ratio perusahaan, di mana hasil signifikansi dari t hitung harus di bawah tingkat signifikansi alpha yang telah ditetapkan yakni sebesar 5\%. Jika signifikansi dari uji statistic $\mathrm{F}$ hitung dan $\mathrm{t}$ hitung lebih besar dari 0.05; maka model tidak dapat digunakan untuk memprediksi kebijakan dividen.

\section{Model Penelitian}

Untuk menguji pengaruh karakteristik perusahaan terhadap pembayaran dividen perusahaan manufaktur yang Go Public di Indonesia Tahun 2015-2019, model regresi berikut digunakan:

$$
\begin{array}{ll}
\text { DPR }= & a+\beta_{1} \text { FCFit }+\beta_{2} \text { CRit } \\
+\beta_{3} \text { SIZEit }+\beta_{4} \text { DERit }+\beta_{5} \text { ROAit }+\beta_{6} \text { AGEit } \\
+ \text { eit } \\
\begin{array}{ll}
\text { Dimana; } & \\
\text { DPR } & =\text { Dividend payout } \\
\text { ratio } & =\text { Free cash flow } \\
\text { FCF } & =\text { Current ratio } \\
\text { CR } & =\text { Ukuran }
\end{array}
\end{array}
$$

perusahaan dengan log natural Total Aset DER $\quad$ Debt to equty ratio ROA $\quad=$ Return on asset AGE $=$ Tahun ke-n (tahun first issue di BEI)

$$
\begin{array}{ll}
\mathrm{a} & =\text { konstanta } \\
\beta_{1}, \beta_{2}, \beta_{3}, \beta_{4}, \beta_{5}, \beta_{6} & =\text { koefisien regresi } \\
\varepsilon & =\text { standard error } \\
\mathrm{i} & =\text { Perusahaan ke-i } \\
\mathrm{t} & =\text { Tahun ke-t }
\end{array}
$$

\section{Hasil dan Pembahasan}

Statistik deskriptif menjelaskan tentang karakteristik data yang digunakan dalam penelitian yang dilihat dari nilai minimum, maksimum, mean, dan standar deviasi. Data diambil dari 37 perusahaan yang listed di BEI. Adapun total pengamatan (oberservasi) yang dilakukan adalah sebesar 185 observasi (37 
perusahaan selama 5 tahun dari 2015 sampai dengan 2019). Data DPR menghasilkan nilai tengah (mean) sebesar 0.4501 yang berarti bahwa rata-rata DPR yang dibayarkan oleh 37 perusahaan selama 5 tahun sebesar $45.01 \%$. Adapun data standar deviasi sebesar 0,2948 mengindikasikan simpangan terjauh dari ratarata terhadap nilai DPR yaitu sebesar $29.48 \%$ serta menunjukan penyebaran data kecil karena nilai standar deviasinya lebih rendah dari nilai rata-rata (mean). Selanjutnya nilai minimum dan maksimum data DPR adalah sebesar 0.0756 (PT Delta Djakarta Tbk tahun 2019) dan 1.8602 (PT Multi Bintang Indonesia Tbk tahun 2015) yang berarti DPR terkecil adalah $7.56 \%$ dan yang terbesar adalah $186.02 \%$. Berikut ini merupakan hasil statistik deskriptif dari variabel-variabel yang digunakan:

\section{Tabel 3}

Hasil Analisis Statistik Deskriptif

\begin{tabular}{cccccc}
\hline Variabel & $\begin{array}{c}\text { Jumlah } \\
\text { Observasi }\end{array}$ & Min & Max & Mean & $\begin{array}{c}\text { Standar } \\
\text { Deviasi }\end{array}$ \\
\hline DPR & 185 & 0.0756 & 1.8602 & 0.4501 & 0.2948 \\
FCF & 185 & -0.4126 & 0.4741 & 0.0641 & 0.1182 \\
CR & 185 & 0.5842 & 21.7045 & 2.9346 & 2.6186 \\
SIZE & 185 & 12.5226 & 19.6790 & 15.4816 & 1.6665 \\
ROA & 185 & 0.0002 & 0.5267 & 0.1072 & 0.0956 \\
DER & 185 & 0.0761 & 4.5469 & 0.8170 & 0.7998 \\
AGE & 185 & 0.0000 & 38.0000 & 21.5405 & 10.1687 \\
\hline
\end{tabular}

Sumber: Data Output Eviews

Perusahaan manufaktur yang menjadi sampel penelitian menunjukkan nilai Free Cash flow rata-rata sebesar 0.0641 dan nilai minimum adalah negatif 0.4126 (PT. Semen Baturaja Persero Tbk tahun 2016) dan paling besar yaitu positif 0.4741 (PT. Astra International Tbk tahun 2015). Kondisi likuiditas yang terlihat dari nilai current ratio yang memiliki nilai rata-rata sebesar 2.9346 dengan standar deviasi 2.6186 nilai minimum sebesar 0.5842 (PT Duta Pertiwi Nusantara Tbk. tahun 2019) dan maksimum sebesar 21.7045 (Multi Bintang Indonesia Tbk. Pada tahun 2015). Ukuran perusahaan terlihat dari total aset menunjukkan rata-rata sebesar 15.4816 dengan nilai aset terkecil sebesar 12.5226 (PT Duta Pertiwi Nusantara Tbk tahun 2015) dan aset terbesar sebesar 19.6790. (PT Astra International Tbk tahun 2019).

Profitabilitas perusahaan-perusahaan manufaktur dilihat dari nilai ROA memiliki ratarata sebesar 0.1072 , bervariasi dari nilai minimum 0.0000 (PT. Industri Jamu dan Farmasi Sido Tbk tahun 2018) dan maksimum sebesar 0.5267 (PT Multi Bintang Indonesia Tbk tahun 2018). Adapun leverage perusahaan diukur dari nilai DER (Debt to equty ratio) ratarata sebesar $81.70 \%$, dengan standar deviasi sebesar 0.7998 , nilai minimum sebesar $7.61 \%$ (PT. Industri Jamu dan Farmasi Sido Tbk tahun 2018) dan maksimum sebesar $454.69 \%$ (PT Indal Aluminium Industry Tbk tahun 2015). Sedangkan nilai umur perusahaan yang dihitung sejak perusahaan tersebut tercatat di Bursa Efek Indonesia memiliki rata-rata sebesar 21.5405 tahun dengan standar deviasi sebesar 10.1687, dengan nilai minimum sebesar 0 tahun (PT Kino Indonesia Tbk yang berdiri tahun 2015) dan maksimum sebesar 38 tahun (PT Supreme Cable Manufacturing Tbk yang berdiri tahun 1982).

\section{Pemilihan Model Terbaik}

Pada pemilihan antara common effect atau fixed effect menghasilkan nilai Chow Test dengan nilai probabilitas $0.0000<0.05$, berdasarkan hal tersebut maka model yang dipilih adalah fixed effect. Adapun Hausman Test yang digunakan untuk menentukan pemilihan model terbaik dalam estimasi data 
panel antara model fixed effect dan model random effect menghasilkan nilai probabilitas $0.0000<0.05$, maka model yang dipilih adalah fixed effect.

\section{Uji Asumsi Klasik}

Hasil uji asumsi klasik semua menunjukkan hasil yang baik yaitu lolos uji multikolinearitas (nilai matriks korelasi $<0.9$ ), uji heterokedastisitas (Uji Glesjer memiliki nilai probabilitas $>0.05$ ) dan uji autokorelasi (dengan nilai Durbin Watson berada dalam antara $1.5953<1.7454<2.2722$ ). Adapun uji normalitas tidak lolos, tetapi menurut Central Limit Theorem (CLT), asumsi normalitas dapat diabaikan Gujarati (2017).

\section{Uji F}

Berdasarkan hasil analisis dapat diketahui bahwa probabilitas F-Statistik yaitu $0.0000<0.05(a=5 \%)$. Hal tersebut berarti bahwa secara bersama-sama variabel free cash flow, rasio likuiditas, ukuran perusahaan, rasio leverage, profitabilitas perusahaan dan umur perusahaan berpengaruh secara signifikan terhadap variabel dividend payout ratio.

\section{$\mathbf{U j i} \mathbf{R}^{2}$}

Hasil uji koefisien determinasi $\left(R^{2}\right)$ dalam penelitian ini memiliki nilai 0.7423 (74.23\%). Hal tersebut berarti bahwa variasi dari variabel dividend payout ratio dapat dijelaskan oleh variasi dari variabel free cash flow, rasio likuiditas, ukuran perusahaan, rasio leverage, profitabilitas perusahaan dan umur perusahaan sebesar $74.23 \%$, sedangkan sisanya sebesar $25.77 \%$ dijelaskan oleh variabel lain di luar model penelitian.

\section{Analisis Regresi Berganda}

Berdasarkan Chow Test dan Hausman Test yang digunakan untukl uji regresi berganda dengan pendekatan data panel mengindikasikan bahwa model data panel yang dipakai adalah fixed effect, sedangkan model telah lolos uji asumsi klasik. Adapun model yang diuji adalah sebagai berikut :

$$
\begin{aligned}
& \mathrm{DPR}=1.9683-0.0000 \mathrm{FCF}_{\mathrm{it}}+0.0050 \mathrm{CR}_{\mathrm{it}}- \\
& 0.0908 \mathrm{SIZE}_{\mathrm{it}}-0.0796 \mathrm{DER}_{\mathrm{it}}- \\
& 2.2988 \mathrm{ROA}_{\mathrm{it}}+0.0086 \mathrm{AGE}_{\mathrm{it}}+\varepsilon_{\mathrm{it}}
\end{aligned}
$$

\begin{tabular}{|c|c|c|c|}
\hline Variabel & $\begin{array}{c}\text { Koefisi } \\
\text { en }\end{array}$ & $\begin{array}{c}\text { Probabil } \\
\text { ity }\end{array}$ & $\begin{array}{c}\text { Keterang } \\
\text { an }\end{array}$ \\
\hline \multirow[t]{2}{*}{ Constant } & 1.96834 & & \\
\hline & 7 & 0.1527 & \\
\hline \multirow[t]{2}{*}{ FCF } & & & tidak \\
\hline & $\begin{array}{c}-8.41 \mathrm{E}- \\
10\end{array}$ & 0.9162 & $\begin{array}{c}\text { berpengar } \\
\text { uh }\end{array}$ \\
\hline \multirow[t]{2}{*}{$\mathrm{CR}$} & & & tidak \\
\hline & $\begin{array}{c}0.00502 \\
8\end{array}$ & 0.6791 & $\begin{array}{c}\text { berpengar } \\
\text { uh }\end{array}$ \\
\hline $\mathrm{S}$ & & & tidak \\
\hline I & - & & berpengar \\
\hline Z & 0.09078 & & uh \\
\hline$E$ & 0 & 0.3665 & \\
\hline \multirow[t]{2}{*}{ DER } & $\begin{array}{c}- \\
0.07964\end{array}$ & & $\begin{array}{c}\text { tidak } \\
\text { berpengar }\end{array}$ \\
\hline & $\begin{array}{l}0 \\
-\end{array}$ & 0.2078 & $\begin{array}{c}\text { uh } \\
\text { Berpengar } \\
\text { uh negatif }\end{array}$ \\
\hline ROA & $\begin{array}{c}2.29884 \\
0\end{array}$ & 0.0000 & $\begin{array}{l}\text { un negatit } \\
\text { dan } \\
\text { signifikan }\end{array}$ \\
\hline \multirow[t]{2}{*}{ AGE } & & 0.5108 & tidak \\
\hline & $\begin{array}{c}0.00858 \\
8\end{array}$ & & $\begin{array}{c}\text { berpengar } \\
\text { uh }\end{array}$ \\
\hline
\end{tabular}

Tabel 4

Hasil Analisis Regresi Berganda

Berdasarkan tabel di atas nilai dapat dilakukan uji parsial atau uji hipotesis sebagai berikut :

\section{Uji t/Uji Hipotesis}

a. Hipotesis 1 : Ada pengaruh antara free cash flow dengan dividend payout ratio Probabilitas sebesar $0.9162>0.05$ ( $a=$ $5 \%$ ) berarti variabel free cash flow tidak berpengaruh secara signifikan terhadap variabel dividend payout ratio atau dengan kata lain Hipotesis 1 ditolak. Free cash flow lebih diutamakan untuk pembayaran hutang kepada kreditor, modal kerja yang dibutuhkan untuk mempertahankan operasi yang sedang berjalan ataupun investasi pada aset 
tetap dibanding didistribusikan dalam bentuk saham tunai kepada pemilik modal. Hasil ini sejalan dengan penelitian Le et al (2019) serta Yusof and Ismail (2017) yang menemukan free cash flow secara signifikan tidak berpengaruh terhadap dividend payout ratio. Penelitian lain yang hasilnya berbeda dilakukan Al Fasus (2020) dan Seherman et al (2015) menyimpulan free cash flow berpengaruh secara signifikan terhadap kebijakan dividen.

b. Hipotesis 2 : ada hubungan antara likuiditas dengan dividend payout ratio Probabilitas sebesar $0.6791>0.05(\mathrm{a}=$ $5 \%$ ) berarti variabel rasio likuiditas tidak berpengaruh secara signifikan terhadap variabel dividend payout ratio atau dengan kata lain Hipotesis 2 ditolak. Hasil penelitian ini menunjukkan bahwa perusahaan tidak akan membayar dividen tinggi untuk menjaga kas perusahaan ketika likuiditas perusahaan mengalami penurunan atau rendah. Perusahaanperusahaan ini juga memiliki banyak cadangan laba yang dapat digunakan baik untuk dibagi dalam bentuk dividen atau diinvestasikan kembali tanpa harus mengubah proporsi pembagian dividen antara investor maupun pemegang saham pengendali (managerial shareholder) dan tanpa bergantung pada besar kecilnya current ratio yang akan diperoleh perusahaan, sehingga berapun besarnya likuiditas perusahaan, perusahaan akan tetap membagi dividen secara rutin setiap tahun melalui cadangan laba perusahaan. Hasil ini sejalan dengan penelitian Tahir dan Mushtaq (2016), Le et al (2019) serta Astakoni dan Utami (2019) menyimpulkan jika likuiditas tidak berpengaruh signifikan terhadap kebijakan dividen. Penelitian lain seperti yang dilakukan Al-Fasfus (2020), Yani dan Dana (2017) serta Saputra dan Pramurza
(2019) menyebutkan terdapat pengaruh signifikan Current ratio (CR) terhadap Dividend payout ratio (DPR).

c. Hipotesis 3 : ada hubungan antara ukuran perusahaan dengan dividend payout ratio Probabilitas sebesar $0.3665>0.05(\mathrm{a}=$ $5 \%$ ) berarti variabel ukuran perusahaan tidak berpengaruh secara signifikan terhadap variabel dividend payout ratio atau dengan kata lain Hipotesis 3 ditolak. Hal ini menunjukkan meskipun perusahaan yang memiliki ukuran yang besar akan lebih mudah memasuki pasar modal sehingga semakin besar ukuran perusahaan semakin mudah untuk mendapatkan modal eksternal dalam jumlah yang lebih besar terutama dari hutang tetapi bukan menjadi jaminan perusahaan akan membayar dividen dengan jumlah besar kepada pemegang saham. Hasil ini sejalan dengan penelitian yang dilakukan oleh Al-Fasfus (2020), Le et al (2019), Samrotun (2015) serta Astakoni dan Utami (2019) menyimpulkan ukuran perusahaan tidak berpengaruh signifikan terhadap kebijakan dividen. Penelitian lain yang hasilnya berbeda dilakukan oleh Yani dan Dana (2017), Tahir dan Mushtaq (2016) dan Jaara et al (2019) menyebutkan jika ukuran perusahaan menunjukkan pengaruh positif yang signifikan untuk membayar dividen lebih banyak dan konsisten.

d. Hipotesis 4 : ada hubungan antara leverage dengan dividend payout ratio Probabilitas sebesar $0.2078>0.05$ ( $a=$ $5 \%$ ) berarti variabel ukuran perusahaan tidak berpengaruh secara signifikan terhadap variabel dividend payout ratio atau dengan kata lain Hipotesis 4 ditolak. Hal tersebut menunjukkan bahwa dengan besar atau rendahnya tingkat hutang tidak memberikan pengaruh terhadap besaran pembayaran dividen. Jika terjadi peningkatan tingkat hutang akan 
mengakibatkan risiko keuangan perusahaan meningkat yang membatasi penggunaan arus kas bebas, sehingga laba yang diperoleh perusahaan akan digunakan untuk membayar kewajibankewajiban perusahaan. Oleh karena itu, leverage keuangan tidak memiliki dampak terhadap keputusan pembayaran dividen perusahaan. Hasil ini sejalan dengan penelitian yang dilakukan oleh Le et al (2019) menunjukkan bahwa faktor leverage keuangan memiliki sedikit atau tidak ada hubungan signifikan dengan keputusan pembayaran dividen. Penelitian lain yang hasilnya berbeda dilakukan oleh Al- Fasfus (2020) dan Samrotun (2015) menyebutkan DER berpengaruh signifikan terhadap kebijakan dividen.

e. Hipotesis 5 : ada hubungan antara profitabilitas perusahaan dengan dividend payout ratio

Probabilitas sebesar $0.0000<0.05(\mathrm{a}=$ $5 \%$ ) dan koefisien sebesar -2.298840 berarti variabel profitabilitas perusahaan berpengaruh negative secara signifikan terhadap variabel dividend payout ratio, jika profitabilitas suatu perusahaan naik $1 \%$ maka pembayaran deviden mengalami penurunan sebesar $2.29 \%$. Hal ini menjelaskan bahwa peningkatan profitabilitas yang dimiliki perusahaan tidak menjamin bahwa perusahaan tersebut juga akan membagikan dividen yang lebih besar kepada pemegang saham. Hasil penelitian menunjukkan bahwa profitabilitas menjadi faktor penentu kebijakan pembagian dividen suatu perusahaan. Perusahaan yang berkomitmen untuk membagikan dividen secara teratur dipengaruhi secara signifikan oleh besar kecilnya keuntungan yang diperoleh. Semakin besar keuntungan yang dihasilkan perusahaan maka semakin kecil dividend payout ratio yang dibayarkan kepada pemegang saham. Perusahaan menggunakan keuntungan sebagai laba ditahan untuk diinvestasikan pada sektor-sektor yang produktif guna memperoleh keuntungan yang lebih besar dan memperkuat modal perusahaan di tahun selanjutnya. Hal ini sesuai dengan pecking order theory dimana pemilihan pendanaan perusahaan didasarkan pada urutan preferensi (hierarki) risiko yaitu laba ditahan, utang kemudian equitas. Hasil penelitian ini sejalan dengan penelitian Silfiana dan Rachmawati (2016) serta Hasana et al (2018) yang menemukan profitabilitas bepengaruh negatif terhadap kebijakan dividen. Penelitian lain yang hasilnya berbeda dilakukan oleh Al- Fasfus (2020), Tahir dan Mushtaq (2016) serta Le et al (2019) menunjukkan bahwa pembayaran dividen berhubungan positif dengan profitabilitas.

f. Hipotesis 6 : ada hubungan antara umur perusahaan dengan dividend payout ratio Probabilitas sebesar $0.5108>0.05$ ( $a=$ $5 \%$ ) berarti variabel umur perusahaan tidak berpengaruh secara signifikan terhadap variabel dividend payout ratio atau dengan kata lain Hipotesis 6 ditolak. Hal ini menunjukkan bahwa meskipun perusahaan sudah lama berdiri dan berada dalam tahap maturity ataupun perusahaan yang belum lama berdiri termasuk dalam tahap pertumbuhan (growth) tidak secara langsung akan mempengaruhi kebijakan pembayaran dividennya. Hal ini sejalan dengan penelitian Al-Fasfus (2020) yang menemukan hubungan tidak signifikan antara umur perusahaan terkait dengan pembayaran dividen. Penelitian lain yang hasilnya berbeda dilakukan oleh Tamimi (2014) menunjukkan hubungan yang positif dan signifikan antara umur perusahaan dan rasio dividen. 


\section{Kesimpulan}

Berdasarkan analisis data dan pembahasan hasil penelitian yang telah dilakukan, maka dapat diambil simpulan sebagai berikut. Free cash flow tidak berpengaruh terhadap dividend payout ratio perusahaan. Hal ini menunjukan bahwa free cash flow lebih diutamakan untuk pembayaran hutang kepada kreditor, modal kerja yang dibutuhkan untuk mempertahankan operasi yang sedang berjalan ataupun investasi pada aset tetap dibanding didistribusikan dalam bentuk saham tunai kepada pemilik modal. Likuiditas tidak berpengaruh terhadap dividend payout ratio, menunjukan bahwa perusahaan tidak akan membayar dividen tinggi untuk menjaga kas perusahaan ketika likuiditas perusahaan mengalami penurunan atau rendah. Ukuran perusahaan tidak berpengaruh terhadap pembayaran deviden, artinya perusahaan besar belum menjamin pembayaran dividen kepada pemegang saham dengan nilai yang tinggi. Leverage tidak berpengaruh terhadap pembayaran deviden, menunjukkan jika terjadi peningkatan tingkat hutang akan mengakibatkan risiko keuangan perusahaan meningkat yang membatasi penggunaan arus kas bebas untuk pembayaran dividen, sehingga laba yang diperoleh perusahaan akan digunakan untuk membayar kewajiban-kewajiban perusahaan. Profitabilitas berpengaruh negatif secara signifikan terhadap pembayaran dividen, apabila perusahaan memperoleh profit tinggi maka laba ditahan akan diinvestasikan pada sektor-sektor yang produktif guna memperoleh keuntungan yang lebih besar dan memperkuat modal perusahaan di tahun selanjutnya sesuai dengan teori pecking order. Umur perusahaan tidak berpengaruh terhadap pembayaran dividen dimana perusahaan dengan ukuran yang besar belum menjamin membayarkan dividen lebih tinggi dari pada perusahaan kecil.

1. Bagi Manajer Manajer sebaiknya lebih memperhatikan return on asset (ROA) perusahaan yang berpengaruh negatif terhadap dividend payout ratio (DPR), sehingga untuk meningkatkan ROA perusahaan maka DPR sebaiknya diturunkan, akan tetapi untuk menjaga harga saham dan persepsi perusahaan di mata investor maka Manajer harus menjelaskan dalam Rapat Umum Pemegang Saham (RUPS) bahwa laba digunakan untuk memperkuat struktur modal dan diinvestasikan kembali pada sektorsektor produktif sehingga dalam jangka panjang akan meningkatkan nilai perusahaan.

2. Bagi Investor

Investor sebaiknya memilih perusahaan yang memberikan dividend payout ratio yang tinggi, dengan mempertimbangkan bahwa return on asset (ROA) dapat berpengaruh negatif terhadap dividend payout ratio (DPR) oleh karena perusahaan cenderung untuk menahan laba daripada mengalokasikan dalam bentuk dividen tunai.

Berdasarkan kesimpulan yang telah diperoleh maka diberikan saran-saran yang sekiranya dapat membantu penelitian selanjutnya yaitu penelitian selanjutnya sebaiknya tidak hanya menggunakan variabel yang sudah digunakan dalam penelitian ini tetapi bisa memperbanyak indikator lainnya yang dapat mempengaruhi dividend payout ratio. Tahir dan dan Mushtaq (2016) menyebutkan variabel lain yang dapat mempengaruhi dividend payout ratio antara lain pertumbuhan penjualan (sales growth) dan risiko bisnis (business risk).

\section{Daftar Pustaka}

Al-Fasfus, F.S. (2020). Impact of Free cash flows on Dividend Pay-Out in Jordanian Banks. Asian Economic and Financial Review Vol. 10, No. 5, 547-558. DOI: 10.18488/journal.aefr.2020.105.547.558

Al-Sabah, T. (2015). The Effect of The Firm's Age and Financial Leverage on its Dividend Policy. Corporate Ownership \& 
Control, 13(1), 24-31.

http://dx.doi.org/10.22495/cocv13i1p3

Astakoni, I.M.P., \& Utami, N.M.S. (2019). Determinan Kebijakan Dividen Perusahaan Manufaktur. Jurnal Riset Akuntansi (JUARA) Vol 9 No 2, 17611788.

http://e-

journal.unmas.ac.id/index.php/juara/arti cle/view/607

Darmawan, A. (2011). Pengaruh Ukuran Perusahaan, Usia Perusahaan, Leverage, Profitabilitas, Struktur Kepemilikan Saham, Investasi, Peluang Investasi terhadap Dividen, Free Cash. Jurnal Aplikasi Manajemen Vol 9, No 4, 14131425.

https://jurnaljam.ub.ac.id/index.php/jam /article/view/1809

Gaol, R.L. (2015). Pengaruh Perputaran Persediaan, Perputaran Piutang Dan Pertumbuhan Penjualan Terhadap Likuiditas Pada Perusahaan Industri Barang Konsumsi Yang Terdaftar Di Bei. Jurnal Riset Akuntansi dan Keuangan Volume 1 No. 2, Hal. 181-202. http://ejournal.ust.ac.id/index.php/JRAK /article/view/167

Gujarati, D.N, \& Porter, D.C. (2017). Basic Econometrics. McGraw-Hill

Hasana, R., Mardani, R.M., Wahono, B. (2018). Pengaruh Free Cash Flow, Profitabilitas, Likuiditas dan Leverage, Terhadap Kebijakan Dividen pada Perusahaan Food and Beverage yang Terdaftar di Bursa Efek Indonesia (BEI) Periode 2014-2016. e -Jurnal Riset Manajemen PRODI MANAJEMEN Vol. 7 No. 12, 88102.

http://riset.unisma.ac.id/index.php/jrm/ article/view/1307

Jaara, B., Alashhab, H., Jaara, O.O. (2019). The Determinants of Dividend Policy for Nonfinancial Companies in Jordan. International Journal of Economics and Financial Issues Vol 8 No 2, 98-209. https://www.econjournals.com/index.ph p/ijefi/article/view/6151
Le, T.T.H., Nguyen, X.H., \& Tran, M.D. (2019). Determinants of Dividend pay-out policy in emerging markets evidence from the Asean Region. Asian Economic and Financial Review Vol. 9, No. 4, 531-546. DOI:

10.18488/journal.aefr.2019.94.531.546

Mayasari, A., Andini, R., Pranaditya, A., Oemar, A. (2018). Pengaruh Perputaran Piutang, Arus Kas, Perputaran Persediaan Terhadap Likuiditas Dengan Profitabilitas Sebagai Variabel Intervening. Jurnal IImiah Mahasiswa S1 Akuntansi Universitas Pandanaran Vol 4, No 4, 1-11 https://jurnal.unpand.ac.id/index.php/A KS/article/view/940/915

Munawar, A.H. (2019). Firm Age Memoderasi ROE dan DER Terhadap Kebijakan Dividen Berdasarkan Index High Dividend 20. Jurnal Akuntansi Volume 14 Nomor 1 , .22-31. http://jurnal.unsil.ac.id/index.php/jak

Samrotun, Y.C. (2015). Kebijakan Dividen dan Faktor-Faktor Yang Mempengaruhinya. Jurnal Paradigma Vol. 13, No. 01, 92103. URL journal.uniba.ac.id/index.php/PD/article/ view/79

Santioso, L., \& Chandra, E. (2012). Pengaruh Profitabilitas, Ukuran Perusahan, Leverage, Umur Perusahaan dan Dewan Komisaris Independen Dalam Pengungkapan Corporate Social Responsibility. Jurnal Bisnis dan Akuntansi Vol.14, No.1 April 2012, HIm 17-30.

https://jurnaltsm.id/index.php/JBA/articl e/view/102

Saputra, D., \& Pramurza, D. (2019). Effect of profitability and liquidity on dividend Policy. Effect of profitability and liquidity on dividend Policy (Empirical Study of Agricultural Sector Companies in the Indonesia Stock Exchange 2014-2017). Journal of Applied Accounting and Business, [S.I.],v.1,n.1, .33-43. 
https://politeknikjambi.ac.id/ojs/jaab/art icle/view/65.

Saputro, W.H.A., Apryana, R., Kalbuana, N. (2017). Pengaruh Profitabilitas, Free Cash Flow, Investment Opportunity Set dan Leverage Terhadap Divident Payout Ratio (Study Empiris pada Perusahaan BUMN yang Terdaftar di Bursa Efek Indonesia Tahun 2011-2015). Seminar Nasional dan The 4th Call For Syariah Paper (SANCALL). http://hdl.handle.net/11617/9218

Sari, I.P., \& Masdupi, E. (2019). Profil Kebijakan Dividen Perusahaan Manufaktur dan Determinannya. Jurnal Kajian Manajemen dan Wirausaha Volume 01 Nomor 02, 44-49. http://ejournal.unp.ac.id/students/index. $\mathrm{php} / \mathrm{mnj} /$ article/view/6396

Silfiana, M., \& Rachmawati, E. (2016). Pengaruh Kepemilikan Managerial, Profitabilitas dan Kesempatan Investasi Pada Perusahaan Manufaktur yang Terdaftar di Bursa Efek Indonesia Periode 2009-2013. KOMPARTEMEN, Vol. XIV No.1, 20-38. http://jurnalnasional.ump.ac.id/index.ph $\mathrm{p} /$ kompartemen/article/view/1370

Singal, A. (2020). Finance for Non-Finance. Executives Business Expert Press Finance and Financial Management Collection.

Suherman, R., Lukman, L., dan Kusnadi. (2015). Pengaruh Free cash flow, hutang dan Tingkat Pertumbuhan Perusahaan Terhadap Kebijakan Deviden Pada Perusahaan Manufaktur Yang Terdaftar di Bursa Efek Indonesia. Jurnal Magister Manajemen Vol 1 No. 2, .209-217.

https://media.neliti.com/media/publicati ons/111615-ID-pengaruh-free-cashflow-hutang-dan-tingk.pdf

Tahir, M., \& Mushtaq, M. (2016). Determinants of Dividend Payout: Evidence from listed Oil and Gas Companies of Pakistan. Journal of Asian Finance, Economics and
Business Vol 3 No 4, 25-37. https://doi.org/10.13106/jafeb.2016.vol $\underline{3 . n 04.25}$

Tamimi, M. (2014). Relationship between Firm Age and Financial Leverage with Dividend Policy. Asian Journal of Finance \& Accounting, Vol. 6, No. 2. URL: http://dx.doi.org/10.5296/ajfa.v6i2.5910

Utomo, W., Andini, R., Raharjo, K. (2016). Pengaruh leverage (DER), Price book value (PBV), Ukuran Perusahaan(SIZE), return on equty $(R O E)$, deviden payout ratio (DPR) dan likuiditas (CR) terhadap price earning ratio (PER) pada perusahaan manufaktur yang listing di BEI tahun 2009-2014. Journal Of Accounting, Volume 2 No.2. https://jurnal.unpand.ac.id/index.php/A KS/article/view/545/531

Yani, M.W.P., Dana, I.M. (2017). Determinasi Kebijakan Dividen Pada Perusahaan Manufaktur di Bursa Efefk Indonesa. Ejurnal Manajemen Unud, Vol. 6, No. 4, 1761-1788.

https://ojs.unud.ac.id/index.php/Manaje $\underline{\text { men/article/view/27269 }}$

YEO, H.J. (2018). Role of Free Cash Flows in Making Investment and Dividend Decisions: The Case of the Shipping Industry. The Asian Journal of Shipping and Logistics 34(2), 113-118. www.elsevier.com/locate/ajsl

Yusof, Y., \& Ismail, S. (2016). Determinants of dividend policy of public listed companies in Malaysia. Review of International Business and Strategy, Vol. 26 Iss 1, pp. 88 - 99. http://dx.doi.org/10.1108/RIBS-022014-0030.

Zurriah, R., \& Sembiring, M. (2018). Pengaruh Free Cash Flow dan Kepemilikan Manajerial terhadap Kebijakan Hutang (Studi Pada Perusahaan Yang Terdaftar di Jakarta Islamic Index). Jurnal Akuntansi dan Bisnis Vol 4 No 2, 31-39 https://ojs.uma.ac.id/index.php/jurnalak undanbisnis/article/view/1664 